\title{
THE POSSIBILITY OF SECONDARY RESOURCE RECOVERY DURING WASTE DISPOSAL SITE RECLAMATION
}

\author{
Natalia Sliusar ${ }^{1, *}$, Aleksandra Krutova ${ }^{2}$, Yulia Mozzhegorova ${ }^{1}$ and Stepan Polygalov ${ }^{1}$ \\ ${ }^{1}$ Department of Environmental Protection, Perm National Research Polytechnic University, Russia \\ ${ }^{2}$ Department of Economics and Finance, Perm National Research Polytechnic University, Russia
}

Article Info:

Received:

27 May 2020

Revised:

8 November 2020

Accepted:

4 December 2020

Available online:

26 February 2021

Keywords:

Landfill

Landfill mining

Dumpsite reclamation

Secondary resources

\begin{abstract}
Nowadays, Russian waste management policies demand the closure and elimination of dumpsites and landfills historically located in the vicinity of populated areas, with no reference to geological and hydrological conditions. Landfill mining is one of the technical solutions for old dumpsite reclamation. The unique feature of this study is the application of an integrated scenario approach in the evaluation of landfill mining projects. This approach is based on a scenario matrix that compares costs and revenues for each scenario, depending on resource and technological capabilities on the one hand, and prevailing economic conditions on the other. It was revealed that for large dumpsites the cost of landfill mining project with waste excavation and redisposal, using landfill soil material, and the recovery of secondary raw materials is several times higher than the cost of baseline dumpsite reclamation. This study shows that implementation of landfill mining projects is feasible for relatively small dumpsites with a low object base area load. The age of a landfill, among the other parameters, has an impact on the economic efficiency of landfill mining project. According to the study the older the landfill is, the higher the content of landfill soil and the lower the amount of secondary raw materials available. As a result, the efficiency and cost of sorting technologies for soil material and secondary raw materials are key factors that determine the economic feasibility of landfill mining during waste disposal site reclamation. Within each scenario, the factors that most influence the total cost are identified.
\end{abstract}

\section{INTRODUCTION}

Throughout its history in Russia, the system of waste management has been based on setting up disposal sites, most of which have been open dumps. Current waste management policies in the Russian Federation (FZ, 1998; ZK, 2001; FZ, 2002) demand closure and elimination of these waste disposal sites. When an old dump or a landfill is situated on an inappropriate area of land, the entire volume of waste must be excavated and redisposed on a sanitary MSW landfill. It is self-evident that the originally designed capacity of sanitary landfills was not intended to accommodate significant amounts of solid waste excavated from old dumps. The fact that the capacity of landfills currently in operation will be exhausted earlier than planned, significantly limits the implementation of Russian dump elimination programs. In this situation, one of the technical solutions for old dump waste reclamation using waste redisposal is landfill mining.

The history of landfill mining began in 1953, when the first project was implemented at a test site near Tel Aviv,
Israel (Ortner et al., 2014; Burlakovs et al., 2017). The main goal of the project was to extract soil material, which was later used to improve the fertile properties of the soil. In Europe, the first landfill excavation project was undertaken in Germany in 1993 at the Bürghof test site in Baden-Württemberg. The project's aim was to assess the technical and economic feasibility of excavation and further processing of waste with a significant shelf life. In Europe, additional landfill excavations were also carried out in Italy, the Netherlands, Austria, Sweden, Finland, Switzerland, Estonia, and Latvia (Sormunen et al., 2008; Krook et al., 2012; Spooren et al., 2013; Ortner et al., 2014; Wolfsberger et al, 2015a; Maul, Pretz, 2016; Bhatnagar et al., 2013; Bhatnagar et al., 2017; Dāce, Bendere, 2017; García López et al., 2018). Projects in the USA and Canada were implemented mainly in 1980-1990 to separate high-calorie fraction (alternative fuel) for energy production (Ortner et al., 2014). In Asia, landfill excavation projects were set up in China, India, Sri Lanka, South Korea, and Thailand. Most of them were aimed at evaluating extracted materials for composting potential (Zhao et al, 2007; Ortner et al., 2014; Weng email: nnslyusar@gmail.com 
et al., 2015). They also assessed the quality and quantity of fine fraction (Mönkäre et al., 2016; Somani et al., 2018; Parrodi et al., 2018), metals (Wagner, Raymond, 2015), and waste for secondary fuel recovery (Siddiqui et al., 2017). Furthermore, a number of projects focused on land reclamation for economic development (Van Passel et al, 2013; Danthurebandara et al., 2014; Wolfsberger et al, 2015b; Hermann et al., 2015; Rechberger, Fellner, 2016; Hermann et al., 2016; Särkkä et al., 2018; Pastre et al., 2018).

In general, there are several reasons to set up landfill mining projects: the extraction of materials with recycling potential; the extraction of materials suitable for energy recovery; the recovery of soil material; and land reclamation (ISWA WG Landfill, 2013; Greedy, 2016). Given the cost of primary resources in Russia, it is generally hardly feasible to embark on landfill mining projects for the extraction of material and energy resources from waste. Nevertheless, landfill mining at open dumps and old landfills is viable and applicable in three circumstances: (1) when a large number of illegal dumps situated on an inappropriate piece of land must be excavated and waste must be redisposed on a sanitary landfill, (2) when urban areas are surrounded by old dumps and landfills which are "growing" into the cities; so these disposal sites have to be eliminated due to the ban on placing such sites in populated areas, and (3) when existent MSW disposal sites are resued to conserve land resources. Today, the most promising direction is the elimination of old MSW disposal sites located illegally near towns.

A typical example for Russia is waste disposal sites in the Perm region (Figure 1).

In the past, the sites for landfills were chosen randomly in the vicinity of populated areas with no reference to the geological and hydrological conditions of the area. As a result, almost every town in the region has its own waste disposal site, often located in a forest or a ravine. In most cases, the area does not exceed one hectare (Figure 2) and most sites are at the stage of active emission formation due to their age (Figure 3).

The transition to modern waste management systems in the Perm region and in the Russian Federation requires the elimination or reclamation of old waste disposal sites. The practice of implementing projects in this area shows that the cost of MSW disposal site reclamation in the Perm region varies from $€ 25,000$ to $€ 65,000$ per 1 hectare (Savelev, 2016; Sliusar, 2019).

Additionally, in most regions, there is a large number of landfills with small disposal site areas. In these cases, it is cheaper to export and dispose waste at a sanitary landfill rather than reclaim an existing site. Considering the capacity limitations of sanitary landfills and the cost of waste re-

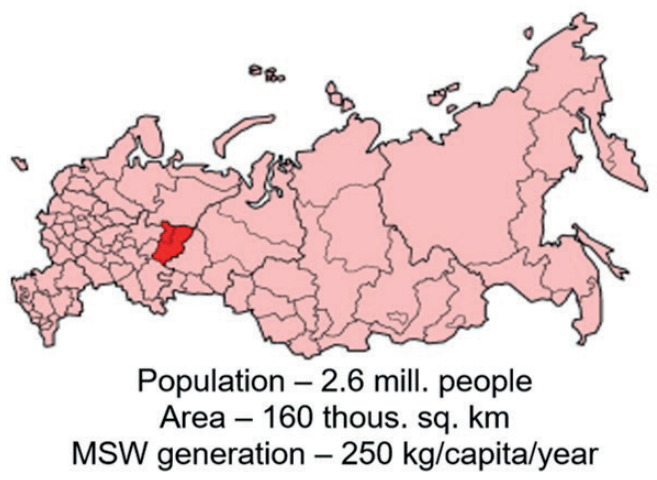

\begin{tabular}{ccc}
\hline & Landfills & Dumpsites \\
\hline Active, units & 32 & 525 \\
\hline Closed, units & 5 & 104 \\
\hline Total square, ha & 205.7 & 812.21 \\
\hline $\begin{array}{l}\text { Total waste } \\
\text { amount, Mt }\end{array}$ & 5,078 & 13,371 \\
\hline
\end{tabular}

FIGURE 1: Number and capacity of MSW disposal sites in the Perm region, Russia.

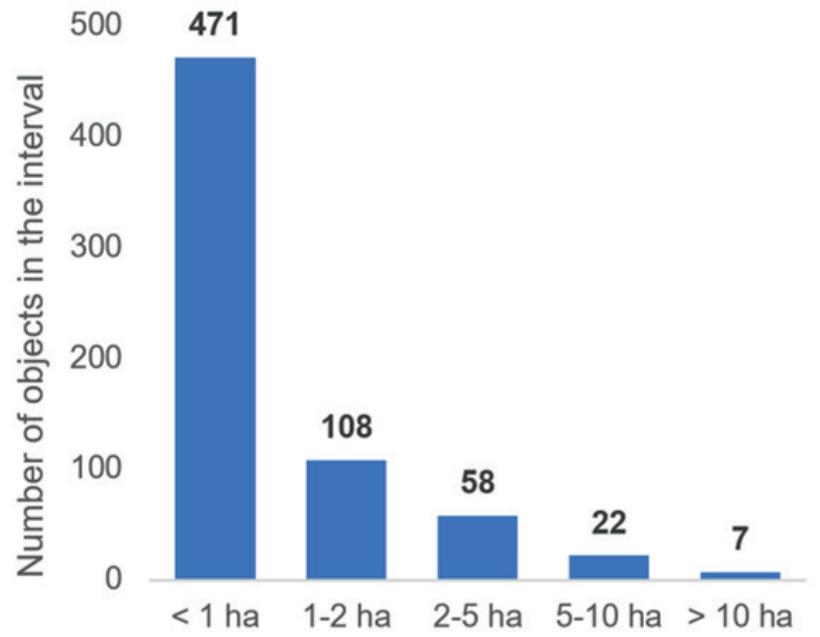

FIGURE 2: Waste disposal sites by site area (Perm region, Russia as an example).

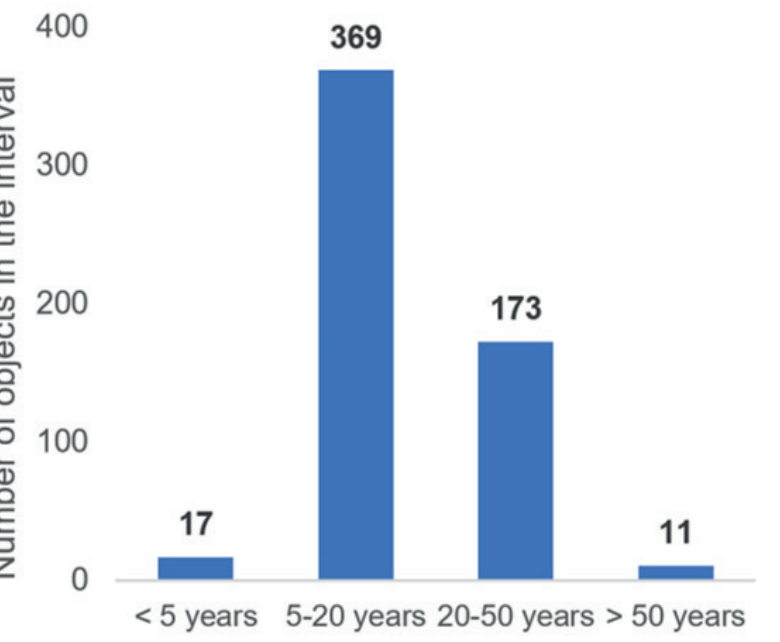

FIGURE 3: Waste disposal sites by age (Perm region, Russia as an example). 
landfilling, the issue of extracting material resources and reducing the volume of disposed waste is a pressing one.

Interest in the topic is confirmed by a significant number of studies on the economic feasibility of landfill mining projects. Some researchers consider the ecological expediency of extracting material resources (Bhatnagar et al., 2013; Danthurebandara et al., 2017), while several other projects evaluate the possibility of using fine fraction waste materials for intermediate and final covering at landfills (Sormunen et al., 2013; Mönkäre et al., 2016. Further studies consider using fine fraction as filling material for land leveling or construction of embankments (Parrodi et al., 2018).

In terms of a project's economic efficiency, more attention should be paid to the extraction of metals (Wolfsberger et al., 2015a; Wolfsberger et al., 2015b; Wagner, Raymond, 2015), the recycling of coarse fractions (Bhatnagar et al., 2013), and the integration of WtE plants into landfill mining projects. However, other researchers have focused on integrated economic efficiency, arguing that total costs (cost of land freed, reduction of environmental load, sale of secondary raw materials (SRM)) are important decision-making factors for the implementation of such projects (Spooren et.al., 2013).

Additionally, there are diverse approaches to conducting analysis. For some authors, the effectiveness of a project includes the entire value chain (Jonce et al., 2012). Others use a comparative approach by analyzing costs when applying different waste treatment technologies (Danthurebandara et al., 2017). There are also various ways to record income from landfill mining projects. Some financial models include only direct income, while others also take indirect earnings into account, such as the sale of a land plot at a higher cost, secondary land use, and taxes (Winterstetter et al., 2015; Wolfsberger et al., 2016).

The key difference in the current study is the application of an integrated scenario approach in determining the expediency of landfill mining projects based on a scenario matrix.

This method allows researchers to compare the costs and profits of each scenario, depending on resources, technological capabilities, and limitations on the one hand, and prevailing economic conditions on the other. The principal advantage of an integrated scenario-based approach is the increased economic feasibility of assessing project implementation technology based on cost and income data. In addition, the model allows for a sensitivity analysis and parameter selection, value changes that have the greatest impact on the total cost

\section{MATERIALS AND METHODS}

\subsection{Description of objects}

Assessment of the economic efficiency of secondary resource extraction in the course of reclamation works was carried out at two closed waste disposal sites:

- Object A: A dumpsite with an area of 12.4 hectares. The volume of waste accumulated at the dumpsite was $550,000 \mathrm{~m}^{3}$. The landfill was in operation from 19572015.
Object B. A dumpsite with an area of 2.4 hectares. The dump is located in a wooded area on the slope of a river, in a water protection zone. It was opened in 1972 and closed to waste reception in 2010. The total amount of accumulated waste at the site was about $30,000 \mathrm{~m}^{3}$.

Objects with different areas were chosen due to differing efficiency in space exploitation. The average waste load was $4.4 \mathrm{~m}^{3} / \mathrm{m}^{2}$ and $1.1 \mathrm{~m}^{3} / \mathrm{m}^{2}$ at sites $A$ and $B$ respectively.

Both properties belong to local municipalities and are located in commercially unappealing areas. Given that the objects were built many years ago, they do not have the type of modern "green" infrastructure (impermeable liners, drainage system, gas collection system, etc.) that ensures proper environmental protection. The nearest sanitary landfill where the waste can be redisposed is at a distance of $20 \mathrm{~km}$ in both cases.

The data on the composition of stored waste was obtained from studies of similar waste mass (Sliusar et al., 2014; Sliusar, 2016) located in the same region, and considering the age of the waste disposal site (Table 1).

\subsection{Scenario matrix description}

A matrix of scenarios is at the core of an integrated approach to the assessment and justification of the feasibility of landfill mining projects.

It allows researchers to assess an object in two dimensions. The first dimension consists of a total cost assessment for four scenarios based on the resources, as well as the technological capabilities and limitations of the object of study. The second dimension includes an evaluation of three scenarios - baseline, optimistic, and pessimistic based on the economic potential of the object of study and the economic situation in the market. The two dimensions of a scenario matrix are considered below.

2.2.1 Dimension 1. Landfill mining project scenarios based on resources, technological capabilities and limitations, and ecological requirements of the object

Scenario 0 (SO). According to Russian legislation (GOST,2015; SP, 201) on the closure of landfills for exploitation, dumpsites are required to complete several procedures, such as waste flattening, passive degassing system installation, laying out clay and vegetation soil materials, followed by land coverage. The thickness of the soil layers depends on the future prospects of using the site, whereas the choice of grass mixture composition depends on local conditions. This scenario is used most commonly in Russian practice, as it requires minimal technical equipment and does not involve waste redisposal. This is the basic option when conducting a feasibility study.

Scenario 1 (S1). If a landfill is located in an unsuitable territory, waste should be excavated and redisposed on the nearest sanitary landfill. Scenario 1 includes the following costs: waste excavation, transportation of the entire waste mass over a $20 \mathrm{~km}$ distance, vacated land plot design and biological reclamation with soil vegetation and land cover.

Scenario 2 (S2) assumes that excavated waste is screened on a mobile screen with landfill soil separation. Studies (Zaytseva, 2006; Armisheva, 2008) have shown 
TABLE 1: Mean value and standard deviation (in brackets) of component and fractional composition of excavated waste.

\begin{tabular}{|c|c|c|c|c|}
\hline \multirow[t]{2}{*}{ Material type } & \multicolumn{4}{|c|}{ Average object age, years } \\
\hline & $1-5$ & $6-15$ & $16-30$ & $>\mathbf{3 0}$ \\
\hline Glass & $9.3(5.6)$ & $6.8(3.1)$ & $6.5(3.1)$ & $4.5(3.0)$ \\
\hline Stone & $11.1(9.0)$ & $17.2(7.1)$ & $12.0(6.8)$ & $11.3(4.7)$ \\
\hline Metals & $2.1(1.9)$ & $1.1(1.1)$ & $2.7(3.1)$ & $3.1(3.5)$ \\
\hline Wood & $8.4(6.3)$ & $6.0(2.6)$ & $10.8(5.6)$ & $9.5(10.5)$ \\
\hline Polymers & $25.9(9.9)$ & $13.1(6.9)$ & $10.3(9.5)$ & $4.2(5.9)$ \\
\hline Textiles & $6.1(5.5)$ & $5.6(6.5)$ & $4.2(5.9)$ & $0.8(0.8)$ \\
\hline Paper & $8.9(7.6)$ & $2.6(2.8)$ & $1.8(3.0)$ & $1.1(2.6)$ \\
\hline Soil materials & $23.7(13.4)$ & $46.6(9.5)$ & $50.6(6.8)$ & $64.0(12.8)$ \\
\hline Other & $4.5(3.7)$ & $1.0(0.7)$ & $1.0(0.8)$ & $1.4(1.4)$ \\
\hline$<20 \mathrm{~mm}$ & $32.6(14.1)$ & $56.3(10.7)$ & $58.2(6.5)$ & $70.3(12.5)$ \\
\hline $20-50 \mathrm{~mm}$ & $14.2(6.0)$ & $13.1(4.4)$ & $10.6(4.0)$ & $9.2(3.8)$ \\
\hline $50-100 \mathrm{~mm}$ & $14.3(4.7)$ & $11.5(2.8)$ & $10.1(2.4)$ & $6.2(3.0)$ \\
\hline$>100 \mathrm{~mm}$ & $39.0(16.6)$ & $19.1(9.1)$ & $21.0(9.5)$ & $14.2(10.0)$ \\
\hline
\end{tabular}

that the characteristics of disposed mass fine fraction are close to those of technogenic soils. In such cases, it is assumed that the recovered landfill soil will be used on the site for land reclamation.

Scenario 3 (S3) also provides for fine fraction separation and its application on the site. In addition, a mobile sorting complex located in close proximity to the site selects SRM (metals, plastic waste and glass). The rest of the waste is transported to a sanitary landfill for subsequent redisposal.

Scenario 4 (S4) is based on recovery and further use of the waste energy fraction (Polygalov et al., 2019). Excavated waste is sifted on a screen, and energy fractions of waste are collected at a sorting facility located next to the landfill site. In the process of sorting out the energy fraction, the heat of waste combustion per working mass increases by 2-3 times (Table 2). When calculating the heat of waste fuel combustion, the contamination of excavated components was taken into account.

2.2.2 Dimension 2. Landfill mining project scenarios based on the economic potential of the object and the economic situation in the market

The feasibility evaluation of MSW disposal reclamation / liquidation scenarios is based on the following initial data sources:

- Earthworks cost (site planning work, upper reclamation layers, fertile soil layers, waste mass degassing) is esti- mated from federal price reference books (SBCP, 2001). - Waste transportation and redisposal are calculated from average market prices in the region.Prices were obtained from the tariff documents published by the Ministry of Tariff Regulation and Energy in the Perm region (Ministry, 2020);

- Sorting materials (fine fraction and recycled materials) cost is calculated from similar facilities and includes equipment rental, along with operating and personnel costs. Prices were obtained upon request of a commercial offer from the equipment owner companies;

- Retail price for recovered secondary resources is set as the lowest in the region due to their low quality (Vtorsyryo159, 2020; Permmakulatura, 2020; Metallpunkt, 2020).

Feasibility evaluation of secondary resources extracted and used during the reclamation and liquidation works is carried out based on the factors in Table 3. Some factors are constant values, such as the operation of equipment, and the cost of soil materials. Other factors, such as waste redisposal cost, recycled waste recovery distance, recycling rate, and SRM cost on the market vary depending on external economic conditions, waste age, recoverable material quality, and sorting technology efficiency. These factors form the basis for three scenarios of dimension 2 : baseline, pessimistic and optimistic.

The baseline landfill mining scenario of dimension 2 implies an economic assessment for selected properties

TABLE 2: Calorific value of excavated waste.

\begin{tabular}{|c|c|c|c|c|}
\hline \multirow[b]{2}{*}{ Age of landfilling, years } & \multicolumn{2}{|c|}{ Untreated waste } & \multicolumn{2}{|c|}{ Energy components (waste fuel) } \\
\hline & Mass, \% & $\begin{array}{c}\text { Calorific value (on working } \\
\text { mass), } \mathrm{MJ} / \mathbf{k g}\end{array}$ & Mass, \% & $\begin{array}{c}\text { Calorific value (on working } \\
\text { mass), } \mathrm{MJ} / \mathrm{kg}\end{array}$ \\
\hline $1-5$ & 100 & 7.08 & 23.4 & 10.94 \\
\hline $6-15$ & 100 & 3.49 & 13.0 & 8.42 \\
\hline $16-30$ & 100 & 2.95 & 12.9 & 8.17 \\
\hline$>31$ & 100 & 1.73 & 7.4 & 6.90 \\
\hline
\end{tabular}


TABLE 3: Factors affecting MSW sites reclamation / disposal economic effect.

\begin{tabular}{|c|c|c|c|}
\hline Impact factor & Baseline scenario & Pessimistic scenario & Optimistic scenario \\
\hline Site works (waste excavation, territory layout, etc.) & \multicolumn{3}{|c|}{ Cost is based on landfill design project } \\
\hline Waste mass density & \multicolumn{3}{|c|}{ Fixed } \\
\hline Waste density after sorting & \multicolumn{3}{|c|}{ Fixed } \\
\hline Waste redisposal & $561 \mathrm{P} / \mathrm{t}$ & Cost increase & Free \\
\hline Waste transport to a redisposal site (distance) & $20 \mathrm{~km}$ & $\begin{array}{l}\text { Depends on the distance to the } \\
\text { next site }\end{array}$ & \\
\hline Landfill soil selection percentage & $30 \%$ (mass) & "young" mass & "old" mass \\
\hline Polymer selection percentage & $10 \%$ (масс) & "old" mass & "young" mass \\
\hline Glass selection percentage & $3 \%$ (mass) & "old" mass & "young" mass \\
\hline Metal selection percentage & $5 \%$ (mass) & "old" mass & "young" mass \\
\hline Energy component sorting & $8 \%$ (mass) & "old" mass & "young" mass \\
\hline Cost of fine fraction sorting & P0.5 thous./t & $\begin{array}{c}\text { Depends on the type of equip- } \\
\text { ment }\end{array}$ & \\
\hline Cost of secondary material sorting & P1.45 thous./t & optical sorting & manual mobile sorting \\
\hline Polymer price & P3 thous./t & $\begin{array}{c}\text { Market decline / low quality } \\
\text { SRM }\end{array}$ & $\begin{array}{c}\text { Market growth / high quality } \\
\text { SRM }\end{array}$ \\
\hline Metal price & P3.5 thous./t & $\begin{array}{c}\text { Market decline / low quality } \\
\text { SRM }\end{array}$ & $\begin{array}{c}\text { Market growth / high quality } \\
\text { SRM }\end{array}$ \\
\hline Glass price & P2 thous./t & $\begin{array}{c}\text { Market decline / low quality } \\
\text { SRM }\end{array}$ & $\begin{array}{c}\text { Market growth / high quality } \\
\text { SRM }\end{array}$ \\
\hline Cost of soil material & & Fixed & \\
\hline
\end{tabular}

at current prices. The assessment determines the technological operations and technical parameters that contribute most to the cost of the baseline scenario.

Optimistic and pessimistic scenarios for landfill mining projects suggest a deviation of the baseline impact factors to the positive or negative side. Factors such as landfill soil extraction and SRM percentage depend on the age of the disposal site and the type of excavated waste processing technology. The prices for SRM and waste sorting operations vary according to the waste treatment and disposal market situation. The data obtained is necessary for analyzing existing situations and forecasting conditions under which the implementation of scenarios will be most economically expedient.

\section{RESULTS AND DISCUSSION}

Material balances of landfill site reclamation are based on two types of data: the composition of waste (Table 1) and the effectiveness of sorting for soil fraction, SRM, and energy components. Figure 4 presents the results of the material flow analysis for the object.

Technically, Scenario 0 (standard reclamation) and Scenario 1 (waste redisposal) are the easiest to execute. However, at the same time, the environmental load in these scenarios decreases slightly, and the resources deposited in the waste are not used.

Landfill mining projects (Scenarios 2 and 3) engage part of the excavated waste into economic circulation, thereby partially covering the excavation and reclamation costs. Studies (Armisheva, 2008; Armisheva et al., 2013) show that landfill soil excavated from old sites can be used as reclamation material to substitute technical soil. Thus, in Scenarios 3 and 4, the volume of redisposed waste can be reduced by $20-60 \%$ (mass.) when excavating young and old disposal sites (in pessimistic and optimistic scenarios respectively).

Scenario 4 (the extraction of SRM) is the most promising scenario since it can provide additional revenue from the sale of excavated SRM (polymer, glass, metal), yet the efficiency of SRM extraction and sorting depends heavily on the waste moisture content at the disposal site. In addition, the price of recycled materials on the market is subject to change and the cost of waste sorting amounts to $50 \%$ of the total project cost.

Figure 5 presents the breakdown of the cost of work under all scenarios (S0-S4) for objects A and B in three versions: baseline, optimistic and pessimistic.

The cost calculation for Scenarios SO-S4 has the same structure. The costs and revenues forall scenarios(S0-S4) for objects $A$ and $B$ are presented in Figure 6 and 7 respectively.

A more preferable scenario for the dumpsite with a higher object base area load per square meter is scenario $\mathrm{SO}$ (for object $\mathrm{A}$, this value is $4.4 \mathrm{~m} \mathrm{MSW} / \mathrm{m}^{2}$ ) (Figure 5) due to the large volume of waste to be excavated. That being said, with a low load on the landfill base (for object $B$, this value is $1.25 \mathrm{~m} \mathrm{MSW} / \mathrm{m}^{2}$ ), the cost of scenario S0 in the basic version is comparable to the cost of work under scenarios S1-S2. This provides an opportunity for cost optimization to ensure the possibility of extraction and further recovery of resources deposited in the waste.

In fact, the cost of scenarios S1-S3 (waste removal, excavation using landfill soil, excavation with extraction of SRM) for large objects with a higher object base area load per square meter exceeds the cost of the baseline scenario (scenario SO) even with the most optimistic course of 

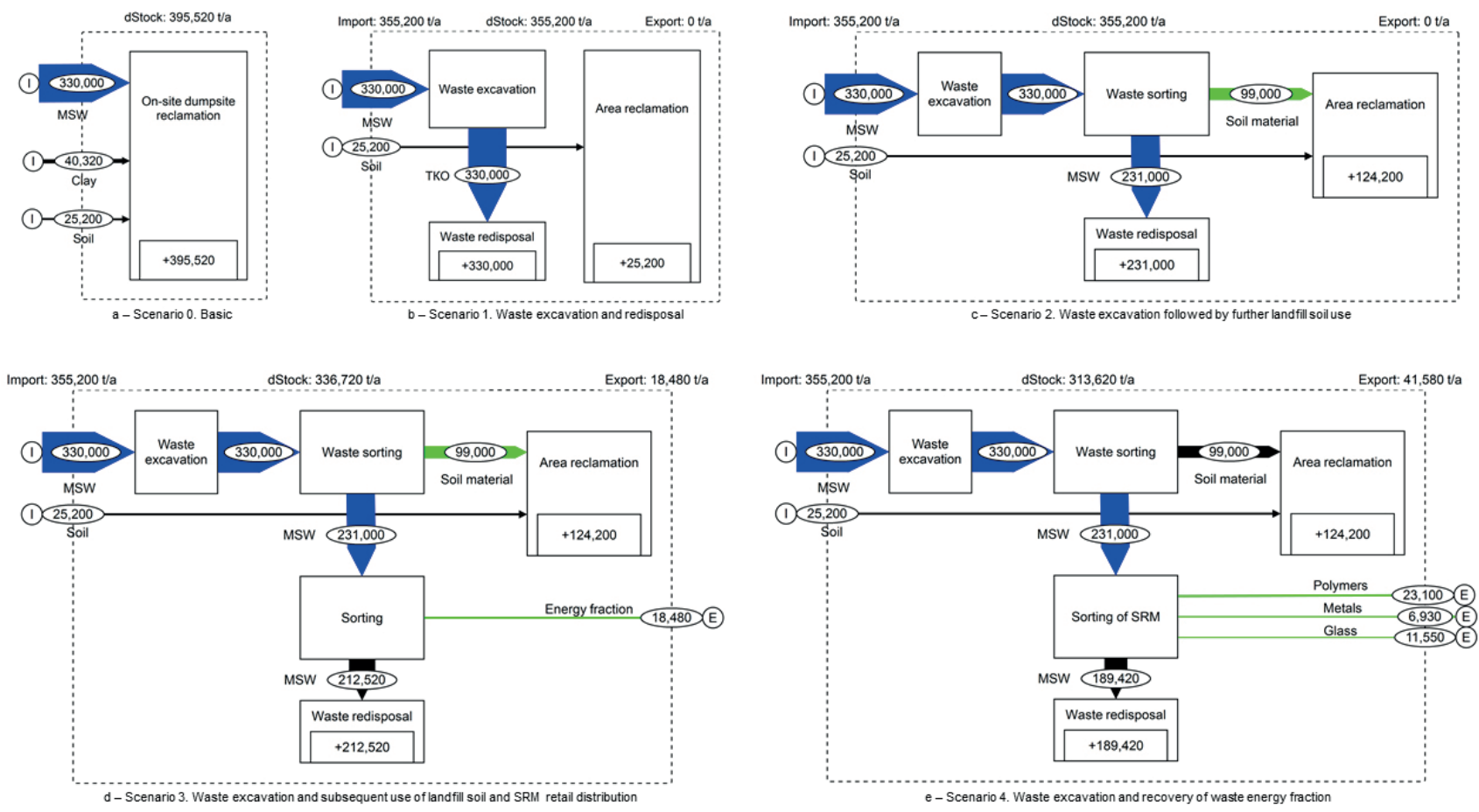

FIGURE 4: Material balance of landfill mining process for object A: a - Scenario 0. Basic; b - Scenario 1. Waste excavation and redisposal; $\mathrm{c}$ - Scenario 2. Waste excavation followed by further landfill soil use; $\mathrm{d}-$ Scenario 3 . Waste excavation and subsequent use of landfill soil and secondary raw material retail distribution; e - Scenario 4 . Waste excavation and recovery of waste energy fraction.
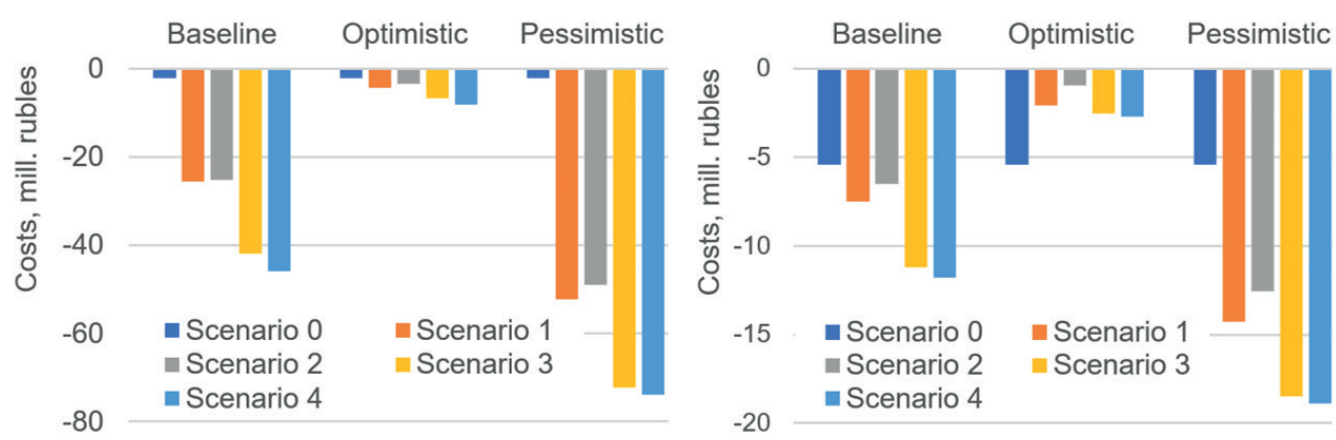

FIGURE 5: Costs for Scenarios S0-S4

events. At the same time, landfill mining projects (scenarios S1-S3) on relatively small objects with a low base area load per square meter become economically viable in the optimistic scenario when compared to the baseline version. For such sites, it makes economic sense to optimize costs of landfill mining projects in order to reduce the negative impact on the environment.

The main costs of scenario S1-S3 (Figure 6-7) are connected with waste redisposal on a sanitary landfill and sorting excavated waste (scenarios S2-S3). Scenario S3 (excavation with the extraction and sale of SRM) should be considered. Though its implementation will significantly reduce the environmental impact compared to other scenarios, the additional costs of sorting SRM several times decrease the revenue from their sale, which makes implementation economically inexpedient.

Thus, the total costs of scenarios S1-S3 (with waste removal, excavation of landfill soil, and excavation with SRM recovery) are lower than the total costs of the baseline scenario so, even for an optimistic course of events. For this reason, the urgent question is which costs of technological operations and technical processes should be reduced in order to reduce the total costs of each scenario?

The cost calculations enable the identification of factors that contribute most to the economic efficiency of a landfill mining project if the most significant parameters change by $1 \%$ (Table 4 ).

For scenarios S1 and S2, one of the most significant parameters is the cost of waste disposal on a nearby sanitary landfill. If fraction is removed from waste and retuned to economic use, it can reduce the amount of recycled waste and consequently its cost.

Scenarios S2 and S3 also include the cost of sorting the fine fraction and SRM from excavated waste, which increases the total cost of implementation. However, this can be controlled and reduced by choosing an optimal 


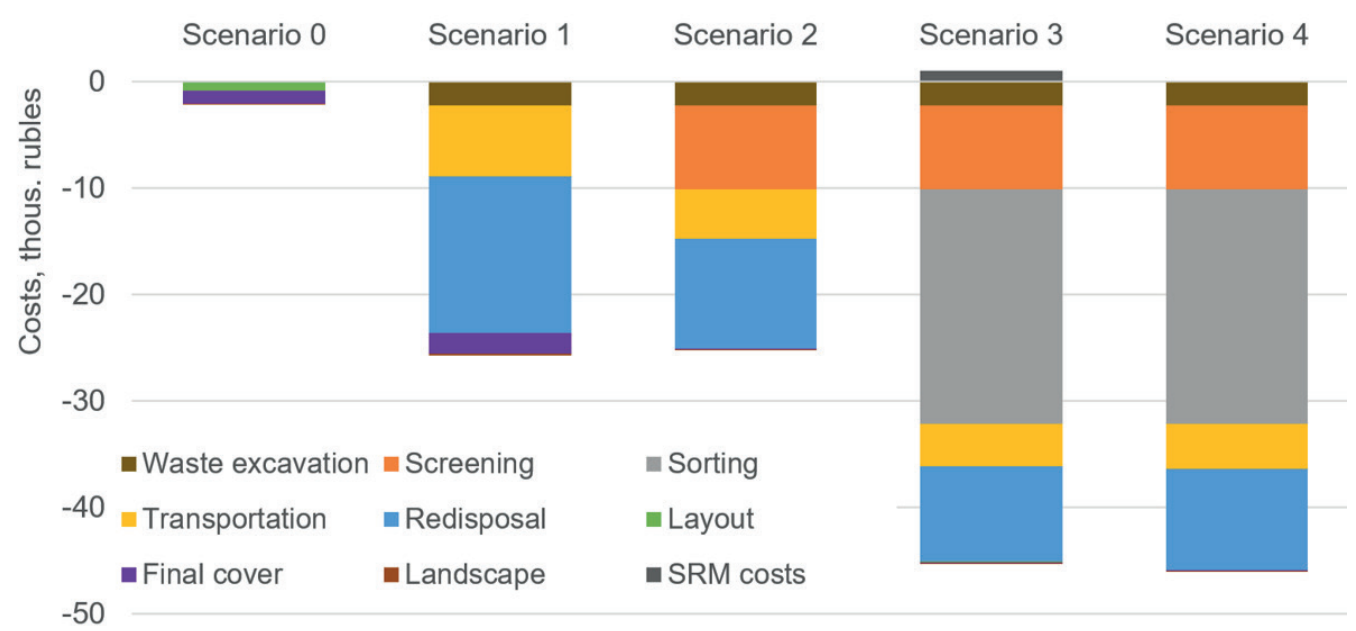

FIGURE 6: Cost and revenue analysis for reclamation / liquidation of MSW disposal site (object A, baseline scenario).

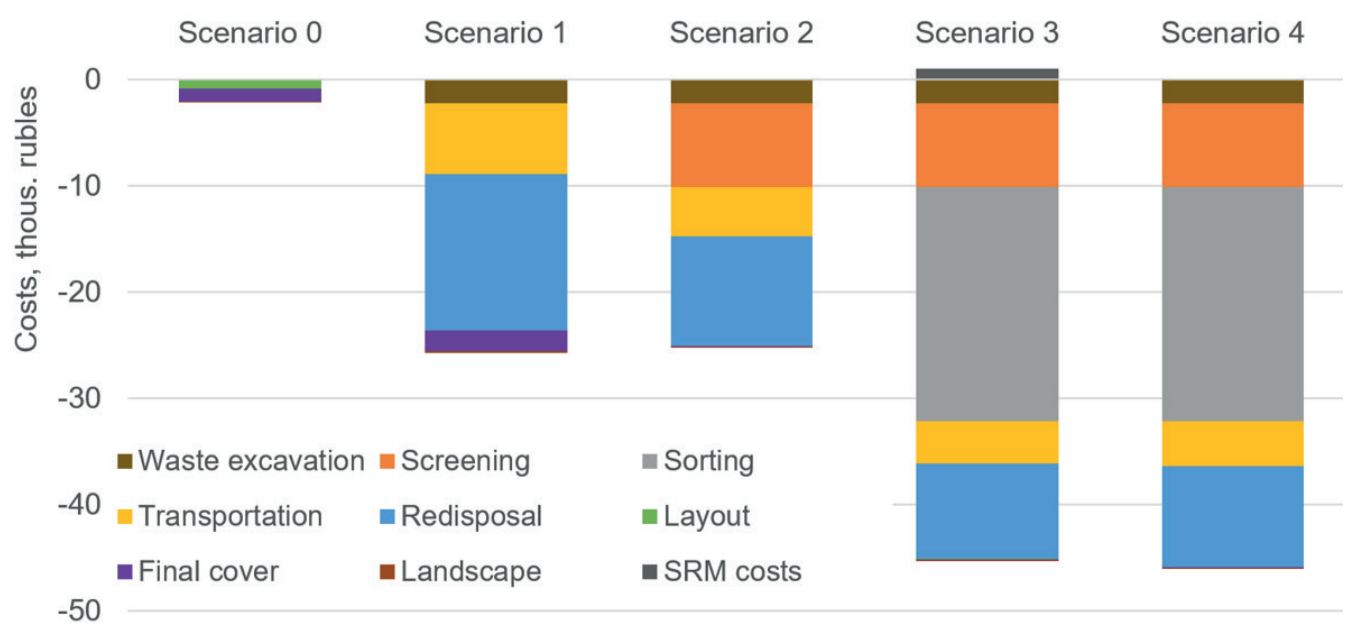

FIGURE 7: Cost and revenue analysis for reclamation / liquidation of MSW disposal (object B, baseline scenario).

technological sorting line, optimizing sorting line operating modes, and installing high-performance equipment. These steps will reduce the cost of work in Scenarios 2-3 (the optimistic scenario), while maximizing the use of the resources deposited in the waste disposal mass.

In the scenarios considered, one of the most significant parameters is the cost of waste disposal on a nearby sanitary landfill. It raises the urgent issue of maximizing fraction removal from waste and returning it into economic circulation.

Another important factor is the cost of sorting the excavated fines fraction and SRM. This variable can be controlled by choosing the optimal technological sorting line, optimizing the operating modes of the sorting lines, or by using high-performance equipment to reduce the sorting cost. In an optimistic scenario, the improved factor can reduce the cost of work in scenarios 2 and 3 , while maximizing the use of the resources in the deposited waste.

Total costs are slightly sensitive to the cost of technological operations and technical processes for objects of various sizes, so the conclusions remain true for objects $A$ and $B$.

\section{CONCLUSIONS}

Based on the studies presented in this article, the decision to extract resources during reclamation of closed waste disposal sites should be carried out while taking into account the environmental requirements along with the technical and economic characteristics of the processes.

The study shows that for large dumpsites with a higher object base area load per square meter, the cost of reclamation with waste excavation and redisposal, using landfill soil material, and the recovery of SRM is several times higher than the cost of basic dumpsite reclamation. On the other hand, implementation of landfill mining projects is feasible for relatively small dumpsites with a low object base area load per square meter. In these cases, it makes economic sense to optimize costs so as to reduce the negative impact on the environment.

There are many factors that affect the economic performance of a landfill mining project in unique ways. Firstly, the age of a landfill is one of the parameters that has an impact on the environmental and economic efficiency of 
TABLE 4: Factors of influence when implementing the scenario-based approach.

\begin{tabular}{|c|c|c|}
\hline \multirow{2}{*}{ Impact factor } & \multicolumn{2}{|c|}{ Factor significance } \\
\hline & Object A & Object B \\
\hline Scenario 1. Landfill mining & Relative divergence & \\
\hline Waste transportation to disposal site & $0.26 \%$ & $0.23 \%$ \\
\hline Waste reburial & $0.57 \%$ & $0.50 \%$ \\
\hline \multicolumn{3}{|c|}{ Scenario 2. Landfill mining with utilization of fine fraction } \\
\hline Fine fraction sorting & $0.31 \%$ & $0.31 \%$ \\
\hline Waste transportation to disposal site & $0.18 \%$ & $0.18 \%$ \\
\hline Waste disposal & $0.41 \%$ & $0.40 \%$ \\
\hline \multicolumn{3}{|c|}{ Scenario 3. Landfill mining with extraction of secondary materials } \\
\hline Fine fraction sorting & $0.19 \%$ & $0.18 \%$ \\
\hline Secondary material sorting & $0.52 \%$ & $0.50 \%$ \\
\hline Waste transportation to disposal site & $0.10 \%$ & $0.09 \%$ \\
\hline Waste disposal & $0.21 \%$ & $0.20 \%$ \\
\hline Secondary material sale & $-0.08 \%$ & $0.04 \%$ \\
\hline \multicolumn{3}{|c|}{ Scenario 4. Waste excavation and recovery of waste energy fraction } \\
\hline Fine fraction sorting & $0.17 \%$ & $0.17 \%$ \\
\hline Secondary material sorting & $0.48 \%$ & $0.48 \%$ \\
\hline Waste transportation to disposal site & $0.09 \%$ & $0.09 \%$ \\
\hline Waste disposal & $0.21 \%$ & $0.20 \%$ \\
\hline Energy fraction sale & 0 & 0 \\
\hline
\end{tabular}

the project. The study results show that the older the landfill is, the higher the content of landfill soil and the lower the amount of SRM available. This is due to the changes in composition of the incoming disposal waste (low proportion of polymers, glass and metals in 20-30 year old waste and a sharp increase of polymers in newer waste), as well as waste decomposition and formation of landfill soil, which is similar to man-made soils.

The efficiency and cost of sorting technologies for soil material and SRM are key factors that determine the economic feasibility of landfill mining during waste disposal site reclamation. The efficiency of the sorting process is linked directly with the quality of the excavated waste. The quality of excavated materials, and as a result the possibility of selecting them from disposal waste, drops significantly in the first 5 years of waste mass. Low volumes of recoverable secondary materials do not cover the high cost of their extraction. Nonetheless, as waste ages, the proportion of soil materials grows, and the quality approaches the quality of technogenic soils. This allows the use of soil materials as a substitute for natural soils during land reclamation and the deployment of deferred resources which improves the economic performance of the process.

\section{AKNOWLEDGEMENTS}

The study was performed with financial support from the Government of the Perm region, Russia within the framework of research projects no. C-26/623 and C-26/174.8.

\section{REFERENCES}

Armisheva (2008). In Russian: Армишева Г.T. (2008). Рекуперация ресурсов при захоронении твердых бытовых отходов // Диссертация на соискание ученой степени кандидата технических наук. Пермский государственный технический университет. Пермь, - 2008. - 179 с [Armisheva G.T. Rekuperacija resursov pri zahoronenii tverdyh bytovyh othodov [Resource recovery in the disposal of municipal solid waste] // Dissertacija na soiskanie uchenoj stepeni kandidata tehnicheskih nauk. Permskij gosudarstvennyj tehnicheskij universitet. Perm'. - 2008. - 179 p.]

Armisheva, G., Sliusar, N., \& Korotaev, V. (2013). Briefing: Urban-mining of landfills. Proceedings of Institution of Civil Engineers: Waste and Resource Management, 166(4). https://doi.org/10.1680/ warm.12.00025

Bhatnagar, A, Kaczala, F., \& Kriipsalu, M. (2013). Closing the Life Cycle of Landfills-Landfill Mining in the Baltic Sea Region for future, presented at Linnaeus Eco-Tech 2012, November, 2012. http://Inu.se/ polopoly_fs/1.78199!SESSION 7 LANDFILL MINING.pdf

Bhatnagar, A., Kaczala, F., Burlakovs, J., Kriipsalu, M., Hogland, M., \& Hogland, W. (2017). Hunting for valuables from landfills and assessing their market opportunities A case study with Kudjape landfill in Estonia. Waste Management and Research, 35(6), 627-635. https://doi.org/10.1177/0734242X17697816

Burlakovs, J., Kriipsalu, M., Klavins, M., Bhatnagar, A., Vincevica-Gaile, Z., Stenis, J., ... Hogland, W. (2017). Paradigms on landfill mining: From dump site scavenging to ecosystem services revitalization. Resources, Conservation and Recycling, 123(July), 73-84. https:// doi.org/10.1016/j.resconrec.2016.07.007

Dāce, E., \& Bendere, R. (2017). Landfill Mining in Latvia, presented at Linnaeus Eco-Tech 2017. https://doi.org/10.15626/ecotech. 2012.011

Danthurebandara, M., Van Passel, S., Vanderreydt, I., \& Van Acker, K. (2014). Assessment of environmental and economic feasibility of Enhanced Landfill Mining. Waste Management, 45, 434-447. https://doi.org/10.1016/j.wasman.2015.01.041

FZ (1998). In Russian: Федеральный закон "Об отходах производства и потребления" от 24.06.1998 N 89-Ф3 [Federal Law 89-FZ, dated 26 Jun. 1998, “On industrial and munisipal waste”] 
FZ (2002). In Russian: Федеральный закон "Об охране окружающей среды" от 10.01.2002 N 7-Ф3 [Federal Law 7-FZ, dated 10 Jan. 2002, "On environmental protection"]

García López, C., Küppers, B., Clausen, A., \& Pretz, T. (2018). Landfill Mining: a Case Study Regarding Sampling, Processing and Characterization of Excavated Waste From an Austrian Landfill. Detritus, 2(1), 29. https://doi.org/10.31025/2611-4135/2018.13664

Greedy, D. (2016). Landfilling and landfill mining. Waste Management and Research, 34(1), 1-2. https://doi. org/10.1177/0734242X15617878

GOST (2015). In Russian: ГОСT P 56598-2015. Ресурсосбережение. Обращение с отходами. Общие требования к полигонам для захоронения отходов [GOST R 56598-2015. Resursosberezhenie. Obrashchenie s othodami. Obshchie trebovaniya k poligonam dlya zahoroneniya othodov [Resources saving. Waste treatment. Technical requirements for specially engineered landfill]]

Hermann, R., Baumgartner, R. J., Vorbach, S., Ragossnig, A., \& Pomberger, R. (2015). Evaluation and selection of decision-making methods to assess landfill mining projects. Waste Management and Research, 33(9), 822-832. https://doi.org/10.1177/0734242X15588586

Hermann, R., Wolfsberger, T., Pomberger, R., \& Sarc, R. (2016). Landfill mining: Developing a comprehensive assessment method. Waste Management and Research, 34(11), 1157-1163. https://doi. org/10.1177/0734242X16657610

Jones, P. T., Geysen, D., Tielemans, Y., Van Passel, S., Pontikes, Y., Blanpain, B., Hoekstra, N. (2013). Enhanced Landfill Mining in view of multiple resource recovery: A critical review. Journal of Cleaner Production, 55, 45-55. https://doi.org/10.1016/j.jclepro.2012.05.021

ISWA Landfill Working Group Key Issue Paper: Landfill Mining. URL: http://www.iswa.org/index.php?elD=tx_iswaknowledgebase_ download\&documentUid $=3224$

Krook, J., Svensson, N., \& Eklund, M. (2012). Landfill mining: A critical review of two decades of research. Waste Management, 32(3), 513-520. https://doi.org/10.1016/j.wasman.2011.10.015

Maul, A., \& Pretz, T. (2016). Landfill Mining from the processing perspective - a view on mass balance and output streams. https:// doi.org/10.13140/RG.2.1.4245.4800

Metallpunkt (2020). In Russian: Пункты приема вторсырья [Recyclable materials point]. Available at: https://metallpunkt.ru

Ministry (2020). In Russian: Министерство тарифного регулирования и энергетики Пермского края [Ministry of tariff regulation and energy of the Perm region]. Available at: http://mtre.permkrai.ru

Mönkäre, T. J., Palmroth, M. R. T., \& Rintala, J. A. (2016). Characterization of fine fraction mined from two Finnish landfills. Waste Management, 47, 34-39. https://doi.org/10.1016/j.wasman.2015.02.034

Ortner, M. E., Knapp, J., \& Bockreis, A. (2014). Landfill mining: Objectives and assessment challenges. Proceedings of Institution of Civil Engineers: Waste and Resource Management, 167(2), 51-61. https://doi.org/10.1680/warm.13.00012

Parrodi J.C.H., Höllen, D, Pomberger, R. (2018). Characterization of fine fractions from landfill mining: a review of previous investigations. Detritus, V. 02, 46-62. https://doi.org/10.31025/26114135/2018.13663

Pastre, G., Griffiths, Z., Val, J., Tasiu, A. M., Camacho-Dominguez, E. V., Wagland, S., \& Coulon, F. (2018). A Decision Support Tool for Enhanced Landfill Mining. Detritus, 01(i), 91-101. https://doi. org/10.26403/detritus/2018.5

Permmakulatura (2020). In Russian: ПермМакулатура. Available at: http://kartona.net

Polygalov, S. Ilinykh, G., Sliusar, N., Korotaev, V., Rukavishnikova I. (2019). Challenges and opportunities for energy recovery from municipal solid waste in the Russian Federation. WIT Transactions on Ecology and the Environment, Vol. 222, 131-143. DOI: 10.2495/ EQ180131

Rechberger, H., \& Fellner, J. (2016). Development of a resource classification framework for old landfills in Flanders (Project RECLAF). In: Proceeding "SUM2016, 3rd Symposium on Urban Mining", 23-25 May 2016, Bergamo, Italy.

Särkkä, H., Kaartinen, T., Hannus, E., Hirvonen, S., Valjus, T., Dino, G. A., ... Coulon, F. (2020). Investigation of Municipal Solid Waste (MSW) and Industrial Landfills As a Potential Source of Secondary Raw Materials. Detritus, 01, 83-90. https://doi.org/10.26403/detritus $/ 2018.3$
Savelev (2016). In Russian: Савельев А.А. Оценка и обеспечение геоэкологической устойчивости массивов твердых коммунальных отходов для строительно-хозяйственного освоения: дис. ... канд. техн. наук. - Самара, 2014. - 323 с. [Savelev A.A. Ocenka i obespechenie geoekologicheskoj ustojchivosti massivov tverdyh kommunal'nyh othodov dlya stroitel'no-hozyajstvennogo osvoeniya [Assessment and provision of geoecological stability of municipal solid waste arrays for construction and economic development] // Dissertacija na soiskanie uchenoj stepeni kandidata tehnicheskih nauk. Samarskii gosudarstvennyj tehnicheskij universitet. Samara. - 2016. - 323 p.]

SBCP (2001). In Russian: СБЦП 81-2001-03 Справочник базовых цен на проектные работы для строительства "Объекты жилищногражданского строительства" [SBCP 81-2001-03 Spravochnik bazovyh cen na proektnye raboty dlya stroitel'stva "Ob"ekty zhilishchno-grazhdanskogo stroitel'stva" [Reference list of basic prices for design work for construction "Objects of housing and civil construction"]]

Siddiqui, F. Z., Zaidi, S., Manuja, S., Pandey, S., \& Khan, M. E. (2017). Development of models for prediction of the energy content of disposed MSW from an unsecured landfill. Waste Management and Research, 35(11), 1129-1136. https://doi. org/10.1177/0734242X17725392

Sliusar, N., Zagorskaya, Y., Korotaev, V. (2014). Studies on waste composition of old landfills and dump sites: case study in Perm region, Russia. Deponietechnik 2014. Dokumentation der 9. Hamburger Abfallwirtschaftstage. - Hamburg, 2014.

Sliusar (2016). In Russian: Слюсарь, Н.Н. (2016). Возможности извлечения отложенных ресурсов из массивов захоронения твердых коммунальных отходов. Вестник Пермского национального исследовательского политехнического университета. Прикладная экология. Урбанистика. - 2016. № 1. - C.63-78. [Sliusar, N. Vozmozhnosty izvlecheniya otlozhennykh resursov iz massivov zakhoroneniya tverdyhk komunalnykh otkhodov [Possibilities for mining of delayed resources on municipal solid waste dumps and landfills] // Vestnik Permskogo nacionalnogo issledovatelskogo politechniceskogo universiteta. Prikladnaya ekologiya. Urbanistika. - 2016. - № 1. - 63-78 p.]

Sliusar (2019). In Russian: Слюсарь, Н.Н. (2019). Теория, методь и технологии обеспечения геоэкологической безопасности полигонов захоронения твердых коммунальных отходов на постэксплуатационном этапе // диссертация на соискание ученой степени доктора технических наук. - Пермь, 2019. - 241 c. [Sliusar N.N. Teoriya, metody i tekhnologii obespecheniya geoekologicheskoj bezopasnosti poligonov zahoroneniya tverdyh kommunal'nyh othodov na postekspluatacionnom etape [Theory, methods and technologies for ensuring geoecological safety of municipal solid waste landfills at the post-operational stage] // Dissertacija na soiskanie uchenoj stepeni doktora technicheskikh nauk. Perm'. - 2019. - 241 p.JSP (2017). In Russian: СП 320.1325800.2017 Полигоны для твердых коммунальных отходов. Проектирование, эксплуатация и рекультивация [SP 320.1325800.2017 Poligony dlya tverdyh kommunal'nyh othodov. Proektirovanie, ekspluataciya i rekul'tivaciya [Polygons for solid communal waste. Projecting, operation and reclamation]]

Somani, M., Datta, M., Ramana, G. V., \& Sreekrishnan, T. R. (2018). Investigations on fine fraction of aged municipal solid waste recovered through landfill mining: Case study of three dumpsites from India. Waste Management and Research, 36(8), 744-755. https:// doi.org/10.1177/0734242X18782393

Sormunen, K., Ettala, M., \& Rintala, J. (2008). Detailed internal characterisation of two Finnish landfills by waste sampling. Waste Management, 28(1), 151-163. https://doi.org/10.1016/j.wasman.2007.01.003

Spooren, J., Quaghebeur, M., Nielsen, P., Machiels, L., Blanpain, B., \& Pontikes, Y. (2013). Material recovery and upcycling within the ELFM concept of the Remo case, presented at International Academic Symposium on Enhanced Landfill Mining, 2013, Houthalen-Helchteren, Belgium

Van Passel, S., Dubois, M., Eyckmans, J., De Gheldere, S., Ang, F., Tom Jones, P., \& Van Acker, K. (2013). The economics of enhanced landfill mining: Private and societal performance drivers. Journal of Cleaner Production, 55, 92-102. https://doi.org/10.1016/j.jclepro.2012.03.024

Vtorsyryo159 (2020). In Russian: Компания «VTOPCЫРьЁ». Available at: http://вторсырьё159.pф 
Wagner, T. P., \& Raymond, T. (2015). Landfill mining: Case study of a successful metals recovery project. Waste Management, 45, 448457. https://doi.org/10.1016/j.wasman.2015.06.034

Weng, Y., Fujiwara, T., Houng, H. J., Sun, C., Li, W., \& Kuo, Y. (2015). Management of landfill reclamation with regard to biodiversity preservation, global warming mitigation and landfill mining: Experiences from the Asia-Pacific region. Journal of Cleaner Production. https://doi.org/10.1016/j.jclepro.2015.05.014

Winterstetter, A., Laner, D., Rechberger, H., \& Fellner, J. (2015). Framework for the evaluation of anthropogenic resources: A landfill mining case study - Resource or reserve? Resources, Conservation and Recycling, 96, 19-30. https://doi.org/10.1016/j.resconrec.2015.01.004

Wolfsberger, T., Aldrian, A., Sarc, R., Hermann, R., Höllen, D., Budischowsky, A., ... Pomberger, R. (2015). Landfill mining: Resource potential of Austrian landfills - Evaluation and quality assessment of recovered municipal solid waste by chemical analyses. Waste Management and Research, 33(11), 962-974. https://doi. org/10.1177/0734242X15600051
Wolfsberger, T., Nispel, J., Sarc, R., Aldrian, A., Hermann, R., Höllen, D., ... Ragossnig, A. (2015). Landfill mining: Development of a theoretical method for a preliminary estimate of the raw material potential of landfill sites. Waste Management and Research, 33(7), 671-680. https://doi.org/10.1177/0734242X15590473

Zaytseva (2006). In Russian: Зайцева T.A. (2006). Закономерности изменения микробиоценозов на полигонах депонирования твердых бытовых отходов в процессе деструкции органических веществ // диссертация на соискание ученой степени доктора биологических наук. - Пермь, 2006. - 289 с. [Zaytseva T.A. Zakonomernosti izmeneniya mikrobiocenozov na poligonah deponirovaniya tverdyh bytovyh othodov v processe destrukcii organicheskih veshchestv [Changes in microbiocenoses at municipal solid waste landfills in the organic substances destruction process] // Dissertacija na soiskanie uchenoj stepeni doktora biologicheskikh nauk. Perm'. - 2008. - 289 p.]

Zhao, Y., Song, L., Huang, R., Song, L., \& Li, X. (2007). Recycling of aged refuse from a closed landfill. Waste Management and Research, 25(2), 130-138. https://doi.org/10.1177/0734242Х07074053

ZK (2001). In Russian: Земельный кодекс Российской Федерации от 25.10.2001 N 136-Ф3 [Land code of the Russian Federation 136-FZ, dated 20 Jan. 2001] 